\title{
THE SPIRIT AND THE ACADEMY
}

\section{David Williams \\ University of Fort Hare}

\begin{abstract}
The lack of interest, even rejection, of the intellectual study of Christianity by Pentecostals and their related movements is not a new feature. On the other hand, their stress on the direct experience of the Spirit has often been derided as irrational. However, the intellectual and "spiritual" must be fundamentally compatible, even complementary. This means that academic study can enhance spiritual growth, and at the same time the nature of the Spirit is such that he can well significantly help the understanding, development and communication of intellectual theology.
\end{abstract}

Key Concepts: Holy Spirit, Pentacostalism, theology

\section{The Priority of the Spiritual over the Rational}

"What has Athens to do with Jerusalem?" exclaimed Tertullian. We are indebted to the third century thinker, brilliant as a lawyer, who did not shrink from applying his acute intellect to that most intellectual of theological issues, that of the Trinity. It is to him that we owe the very word "Trinity", and insights that laid a firm foundation for Western thought on the issue, enabling its steadfastness throughout all the controversy of the succeeding centuries (Milne 1997:294). Yet it was this same thinker who threw over the intellect for the "Pentecostalism" of the time and became a Montanist. It would seem that he could see only a fundamental dichotomy between the rationalist thinking symbolised by the intellectual centre of the day and the spirituality that emanated from the Jews (Milne 1997:12).

It would seem that his rejection of intellectualism was even something that met with divine approval. Quite a while later the gifted Jerome was reportedly reproved by his Lord in a dream, "you are not a Christian but a Ciceronian!" (Foakes Jackson 1914:481).

This rejection of the intellectual had never been far from the surface in the early Christian centuries. This is hardly surprising when some of the initial challenges to the Christian faith were the various Gnostic systems, which saw salvation in the acceptance of specific secret knowledge. Such an attitude has always been a temptation, and even today it is not uncommon for a deviant set of ideas to be termed "gnostic". A good example of this is the ideas of New Age teaching (Williams 1971:27), or the so-called "prosperity teaching", which sees spiritual, and therefore health and material blessing, as a result of acceptance and practice of a distinct set of ideas (Swaggert 1980).

Indeed, it is right there in the pages of the New Testament itself, where Paul contrasts the wisdom of his day with being led by the Spirit (1 Cor 1:20f). In fact, it is probably true to say that the gospel of grace must always be in a measure irrational, open to the accusation of injustice when great sinners can be saved on the same basis as the saints, and even of encouraging anomianism (Rom 6:1f). Justice has a new understanding in the era of grace (Taylor 1971:100). The latter is not just a matter which follows from the severance of judgement from salvation, but from the fact that Christians are directly led by the Spirit and not 
by a codified, so rational, legal system. This means that just as with their Lord himself, Christians may sometimes have to disobey the law in order to act righteously. The classic case of this is the cry of Peter and John to the Sanhedrin that "we must obey God rather than men!" (Acts 5:29). Christians have always claimed this right, from the times of the persecutions under Rome to those under apartheid. Guidance by the Spirit supersedes the rule of law and of reason.

It can even be traced back further than that into disputes between legal rulers and priestly upholders of the system and those turbulent prophets, who claimed a God-given right and guidance to say what they did. Their claim was "Thus says the Lord", perhaps the equivalent of Jesus' "amen I say to you" (Taylor 1971:96). It must then be observed that the sympathy of later believers is always with the latter. The prophets may well have been rejected at the time, but later assessment is that they were right in their rejection of the cold logic of the day. The Spirit is indeed over the law.

The antipathy to the academic is certainly something that has been characteristic of the modern Spirit movement of Pentecostalism and its successors in the Charismatic movement and the so-called "third wave". There has been a profound mistrust of academic enterprise and training amounting to a rejection of it. Strauss (1954:12) laments the fact that many have had a thorough training, but have a powerless ministry. Young Christians have been repeatedly advised against academic theological study as it has been felt that this will inevitably damage the tender shoots of young faith, and quench the fires of the Spirit (e.g. Laurentin 1977:184). It has been realised that valid experience does not need accurate doctrine (Wheeler Robinson 1928:138). However, even the mainline churches have tended to want to train their own ministers, although this is at least partly to maintain their own distinctiveness. The result of this separation has, however, been a loss of real contact with the world and its problems, so an encouragement of irrelevance (Williams 1997:7). In southern Africa, one of the major factors in the growth of the so-called "African Independent Churches" and so of loss to the traditional denominations, is of a perceived concentration on the intellect while at the same time a neglect of the Spirit, and so a loss of relevance to the "real" issues of life such as disease.

The distinctive of Pentecostalism, the so-called "baptism of the Spirit", however this has been understood, has not been associated with the rational and intellectual. The original Pentecostalism, with its roots in the Holiness movement, related it to a deeper experience of God, and so effectively with sanctification. Neither emphasis related to intellectual ability or its enhancement.

Pentecostalism, in the wider sense of the word, has generally concentrated on experience, and only secondarily sought to understand it, let alone systematise it (Bruner 1970:21). It has been sought at the expense of understanding doctrine (Hummel 1993:18). Christian bookshops contain a plethora of books explaining the "how" of spiritual experience and growth, but almost nothing on understanding the faith. This is of course partly because Christian experience must always be irrational, at least to an extent, and this is particularly the case for the exercise of the charismata. Even the gifts of "wisdom" and "knowledge" (cf Hummel 1965:65) are not rational in the full sense. They may well manifest in those who are the least naturally endowed with such abilities (Williams 1971:21). The gift most associated with Pentecostalism, glossolalia, is inherently non-rational (not irrational (Hummel 1993:127)), as it is the exercise of the voice with no control by the mind. Even when it is interpreted, there need actually be no definite link with the original utterance. Interpretation is not translation. The same is true of the phenomena more associated with more recent developments. "Slaying 
in the Spirit" and the "Toronto blessing" are both claimed to occur when the rational control of the mind is relaxed. In the former case, there has been a great deal of work done in an attempt to understand what is going on; interestingly most research seems to suggest that glossolalics are generally more balanced as a group than non-tongue-speakers (Laurentin 1977:151).

Then there have then been a lot of attempts to place the experiences into a theological system, which means either justifying the experience from a Biblical point of view or saying that the Biblical accounts of a "second blessing", especially as recorded in the book of Acts, were all unique events (Packer 1995:206, cf also Bruner 1970:63f). Even if there are still some who dare to persist in the belief that all modern claims are false, that the Biblical phenomena were either mythical or died out very soon in the history of the church (eg Gaffin 1996), there are just too many who claim to have had such an experience, even if very few of them seem to have any desire to explain it rationally.

When it comes to the more recent phenomena, attempts to justify them Biblically are much harder and at best strained. Again, most want just to accept them as self-authenticating. Indeed some groups which practise them refer to themselves as "Word and Spirit churches" (Porter 1995:38), thereby implying that even if much of their belief is based on the Word, so on the Bible, some aspects of experience come from the sovereign activity of the Spirit, and so do not need intellectual justification. In a sense, just as with Jesus, the Spirit's authority is selfauthenticating (Taylor 1971:95).

Indeed, if God is a Person, he cannot be restricted to logic, and must always be free to act unpredictably, exerting sovereign choice. Interestingly, those most rational of Christians, the Calvinists, are also those who most prominently stress the sovereign choice of God in selecting some and not others with no reference to whether they deserve it or not, that salvation is by unmerited grace and in no sense earned. It is this aspect which is currently causing such a furore in American Evangelicalism, where the "open theists" (e.g. Pinnock 2001) are insisting that people do indeed have free will and therefore the future cannot be known. God is omniscient, but because choice is free, the future is inherently unknown, even by God. Then if unpredictable choice is true of people, how much more of God?

\section{Rejection of the 'Irrational'}

Of course, the rejection of the rational is reciprocated. Those "more spiritual" have always been accused of being irrational (so wrong), fanatical and enthusiastic (so unbalanced, which is a cardinal sin of the academic). It may well be hard to fit the action of the Spirit into traditional theological categories (Williams 1971:39). Again, the attitude can be quickly seen in a desire to regulate the "spiritual" by creed and by hierarchy, both symbolic of logic, in the development of the early church (Taylor 1971:208). Even today, theology by its very nature can tend to stifle the Spirit (Brunner, cited in Williams 1971:80). The theologian can be the last holdout against the Spirit, but conversely can do much to aid his activity (Williams 1971:113). The prophets likewise were despised; "the man of the Spirit is mad" (Hos 9:7). This negative impression is part of the reason why there is almost no reference to the Spirit in them; they stressed the reception of the "Word", which is quite correct as they revealed the desire of God, but they wanted to avoid any contamination with the reputation of the ecstatics. Even the reference to the Spirit in Micah 3:8 has been felt to be an interpolation (Moule 1978:61). It is a small step from "spiritual experiences" to chaos, and so Paul had to lay down a number of basic guidelines for the exercise of the charismata at Corinth (1 Cor 14).

Perhaps it is far from accidental that immediately after the Edict of Milan in 313 AD came 
the explorations into theological logic in the Arian controversy, and even less accidental that in that controversy the interest in the Spirit was minimal. He received a bare mention in the original Nicene creed, and only a little more when the final formulation was accepted at Constantinople in 381 AD. Quite clearly spiritual experience, especially of an "illogical" nature, was no longer an issue. Even if there was still some experience of the charismata in Augustine's day, there had been a distinct decline after the first two centuries (Hummel 1993:79f).

Right through the scholasticism of the Middle Ages, and through the changes in the Reformation, rationality and logic reigned supreme. Luther had some of his harshest words for the "fanatics" of his day, the "radical Reformation" or the Anabaptists. Doctrine must be based on the scriptures only, which are sufficient (cf. also the Westminster Confession 1:6, cited by Oss 1996:169). The message of the church must be logical, must appeal to the mind; any appeal to the emotion must be secondary. The mind is exalted at the expense of other aspects of humanity (Hummel 1993:128). This is epitomised most clearly in the division in Aquinas' theology between matters that pertain to the One God, and those pertaining to his threeness, very much a subsidiary issue. Logic and philosophy override experience. Of course a stress on God as One must naturally tend to the intellectual; a study of the "attributes of God" always tends to the philosophical. On the contrary, the Christian experience of God is three-fold. So strong is that emphasis that Rahner (1970:11) could complain that if the Trinity was removed from Christian doctrine, it would make hardly any difference to the faith of most Christians. We have adopted the old dichotomy between spirit and the world (Taylor 1971:42); we are still suffering the legacy of neo-orthodoxy.

It could perhaps be that this rejection involves a trace of guilt, simply because the exercise of spiritual gifts must go along with a measure of sanctification. After all, the one who gives the gifts is the Holy Spirit. Wesley did not deny the possibility of the gifts in his day, but ascribed their rarity to spiritual coldness (Hummel 1993:83). It can hardly be an historical accident that the decline in spiritual gifting coincided with the growth of the early church, and especially when it became "politically correct" to be a Christian. Nominal Christianity had become the norm (Hummel 1993:137). Such a nominal status can hardly be conducive to spiritual life. Even Jesus could do no great works in a situation of unbelief (Matt 13:58). The Ephesians of the Revelation were warned that Jesus would remove their lamp stand, which must refer to spiritual activity ( $\operatorname{Rev} 4: 5)$, unless they returned to their first love ( $\operatorname{Rev} 2: 4)$.

It is perhaps ironic that at the same time that there had been a neglect of the Spirit there had been a move towards a reliance on that same Spirit insofar as he was seen as the source of the scriptures, and that by direct inspiration. The Word demanded the Spirit. The prevalent view, at least until modern times, had been of the essential passivity of the human writers, that they were given the material directly from God, and just wrote it down. The scriptures could then be given authority, as in the Reformation affirmation of sola scriptura, because they were indeed the ipsissima verba Dei. It has, however, been increasingly realised that even the prophets had a big input into at least the form of their oracles (von Rad 1968:52), and it would seem much more reasonable, and in keeping with his normal way of action, that what the Spirit did was more often give understanding to their knowledge of events, so not so much give material, but enliven it. Certainly it would seem to be Luke's idea, indicating that his material came essentially from human research (Lk 1:1-4). Then what the Spirit did was to relate the author to his understanding. 


\section{Word and Spirit}

It may validly be suggested that there is a fundamental division between the action of the Spirit and the mind, so with rationality. The Spirit fundamentally acts upon the human spirit; "the Spirit is that power which operates on the heart" (Dunn 1975:201). Therefore he motivates the will, but not so much the mind. The holiness which he generates is largely motivational, not a matter of intellectual persuasion. Perhaps this is why many have seen the Spirit as more feminine in her workings? The Spirit deals with questions of "why", rather than the "how" of the mind; indeed this is the main difference between science, the epitome of logic, and religion, matters of the Spirit, which answer different kinds of questions.

Even if a distinction is valid, a separation between the rational and the spiritual, a new form of dualism, can hardly be right. Indeed, this has been recognised by the Pentecostals, who very quickly moved to establish their own training institutes, where even if the curriculum was hardly recognisable from a traditional perspective, the principle of intellectual training was obviously accepted. Bishop Temple once said that "The main function of the Church is religious education, that is to say, the building up of thought and character, in the knowledge of the Love of God, so that the soul is always open to the operation of the Holy Spirit" (Wheeler Robinson 1928:153). What is tragic from the point of view of the church is that this trend actually added to the increasingly entrenched division between the traditional and the Pentecostal, to say nothing of the tremendous waste of resources in the duplication of staff, libraries and other facilities. In any case, it hardly seems right that colleges training servants of the same Lord should end up as rivals to each other. Unified training is not only good sense economically, but is more in keeping with the Gospel (Rowdon 1968:16).

More serious is the fundamental division in Christian experience, a division which seems to penetrate to the heart of the Godhead. There has always been a tendency to concentrate on one Person of the Trinity and to neglect the other two (Boff 1988:13f). The neglect of the Spirit is, sadly, more likely when Christianity becomes truer to its name and becomes more definitely Christological. An emphasis on the second Person, the logos, elevates revelation and logic. At least the study of the Person of Christ is more definitely linked to the Christian claim to experience, that is, of salvation. After all, it was Athanasius' appreciation that full salvation could only be accomplished by a Christ who was totally divine, that prompted his insistence that any hint of subordination was impossible for the faith.

Although Athanasius made the same affirmation, for the same basic reason, about the nature of the Spirit, interest in the doctrine continued to decline, and for centuries the Spirit could be termed the "forgotten Person". And yet Christian faith is totally dependent upon what the Spirit does. Although God, specifically the Father, must be transcendent, he still relates to the world, but unless that transcendence is to a measure compromised, this must be via the Spirit as well as by Word, which is indeed an affirmation of Old Testament theology. It is the Spirit, one of Irenaeus' "two hands of God", through whom God acts in the world. Otherwise God becomes a deistic creator and law-giver, absent from the world and effectively irrelevant to it. At the same time the work of Christ remains an incident confined to a specific time and place unless the Spirit links it to the believer. The point is that Christian faith must be inherently "Spiritual" by its very nature. Wheeler Robinson (1928:230) comments that for Paul, Christian experience moved wholly in the realm of the Spirit, "both upwards towards Christ as the source of grace and life, and downwards into the charismata and the fruit of the Sprit in conduct and character." Any portrayal of Christianity can hardly delegate the doctrine of the Spirit to a later insignificant chapter, subordinate to matters of "real theology". Is there not 
here a hint of the heresy that treats only the Father as truly God? After all, the very incarnation, perhaps the central Christian affirmation, was through the coming of the Spirit upon Mary. Jesus could only be the Word through the Spirit. The nature of Jesus is only comprehensible by the Spirit; it is really impossible to be Christocentric while ignoring the role of the Spirit (Wheeler Robinson 1928:139). Taylor (1971:45) insists that what the church needs is a sense of "beyondness", recovery of wonder.

But this does not really make the Spirit much more than of intellectual importance, affirmed due to Trinitarian necessity. What is then irrational is if the Spiritual dimension of faith is still ignored. The rational and "irrational", the objective and subjective, the Word and Spirit, must both have a place, must be complementary in a full Christian understanding. Wheeler Robinson (1928:155) comments that the mingling of the objective and subjective is "of the very nature of Christian truth". Archbishop Carey recently called for "a partnership of theology and experience, each informing the other" (Hummel 1993:256). One of the tragic results of the Enlightenment has been the division of knowledge and experience into distinct "compartments" (Williams 1997:5); this is, however, now less the case in a post-modern world. In this regard, Gaffin (1996:27) notes the observation of the affinity between charismatic spirituality and postmodernism. However, religion deals with "knowing God" as well as knowing about him, and even if each is perfectly possible without the other, they are complementary. Experience is the source of doctrine, but doctrine can enrich the experience (Wheeler Robinson 1928:139). The utterance of words requires breath, a common metaphor for the Spirit, sanctified by Jesus' use of it (Jn 20:22), and words can convey spirit. Thus Williams (1971:32) notes how tongues and rational prayer can complement each other.

However, the fact that there is a difference does mean that questions of religious life are often not really teachable in an intellectual way which neglects the Spirit. Aspects such as prayer cannot ultimately be taught, although as with everything, knowledge of it, especially the insights of the past, is useful. An interesting comment in this regard is that even in seminaries, many students testify to learning more about the practice of their faith from the academic professors than from the classes specifically designed for that purpose (Feilding 1966:13). The corollary of this is that universities, which may be accused of neglecting the spiritual life of their students, can, with the right staff, make a positive contribution in this regard. But even with the less directly "spiritual" matters, because the Spirit is fundamental to our understanding of the nature of God, so he is likewise fundamental to any study of God. He is, after all, the "Spirit of truth" (Jn 14:17, 15:26).

\section{Theological Study}

This immediately gives a place to theological study. Unless religion is actually a myth, a set of beliefs and practices reflecting no objective reality, it is fundamentally a relating to God, which is through the Spirit. Religion is only really intelligible from within (Wheeler Robinson 1928:25). Its core is experience. Then as with any human experience, not least in science, observations are recorded and then systematised. This latter step involves the proposal of hypotheses to try to understand specific experience in the light of the whole of reality. Such hypotheses can then function as means of assessing and understanding further experience, as well as enabling a more efficient communication of those experiences to later generations. Through this process, each generation can benefit from the past; there is no need to "re-invent the wheel".

This defines the role of a theological institution. Firstly it seeks to transfer knowledge to the 
next generation, then secondly, unless it is a purely teaching institution, it is involved in the development of knowledge, so recording experience, critiquing it, organising material, and applying it to concrete situations. Not only is the Spirit the source of the original material, so of experience, but he facilitates all of these aspects. This is because his fundamental role is generating relationship, acting as vinculum amoris. Just as he acts in the Trinity as the bond between Father and Son, and relates people to the Father and Son in the fullness of salvation, so also he facilitates the relationships of theological study.

Thus he facilitates the transfer of knowledge to the student by enhancing the bond with the teacher. Just as a preacher may experience the inspiration of the Spirit in the delivery of a sermon or other address, so he enables the communication process, whether in mission (Taylor 1971:21), or in Christian education. Likewise he acts in the student enhancing receptivity; there is bonding to the material. This should be similar to the process by which the prophet heard the word of God being spoken. (Incidentally, prophecy is not the same as preaching (Williams 1971:28). Nevertheless they are related; while the former is fundamentally divine in origin, but formed by human ability, the latter is its complement, fundamentally human, but empowered by the Spirit.) Then for both teacher and student, the bonding process should enhance the retention of the memory and its production at appropriate times. This aspect was particularly highlighted by Jesus (Jn 14:26). One thing that both the teacher and the student must be aware of in this context, not to forget the preacher, is that the Spirit quickens and interrelates already existing material. This can be seen in his role in the creation process, not producing the material, which is the role of the Son (1 Cor 8:6), but giving life to it (Gen 2:7, also Ez 37:9), seeing that life is essentially a process of inter-relating (Williams 2002:274). The role of the Spirit is no substitute for preparation and study; he does not enliven what is not already there!

Thus the Spirit tends to aid human effort rather than acting directly. In much of what the Spirit does, he is a "helper", which is a common translation of the Johannine term parakletos. Even a gift such as glossolalia is a help to prayer, enhancing the activity that is initiated not by God but by the one praying. Indeed, it would seem that God has a reticence to act unless a human solution is impossible. An example of this is that healing miracles rarely occur when a solution to the problem is within normal human capabilities. Even what Jesus did was almost totally in matters where there was no normal solution. This aspect again means that the input of the Spirit is likely to be overlooked; human nature being what it is, we tend to be too proud to ask for help, accept a poorer quality result, and even forget that something better is a possibility.

The same facilitating of inter-relating by the Spirit is also seen in the academic process. He inspires the inter-relating of material, so its systematisation, which of course also enables its understanding. Likewise, of course, critique and application are also aspects of relationship, so enhanced by the Spirit.

The academy then has a constant problem in motivating its students to really study. Traditionally one way in which it does this is by recognition of achievement, evaluated by such as tests and exams. It uses the natural human response to competition. Spiritual achievement, on the contrary, is not quantifiable and can therefore be readily neglected. It is also by no means irrelevant that spirituality often involves kenosis, or self-abasement, but that those who follow this precept of Christ (Phil 2:1f) can well find that as with their Lord, they are mocked and despised, and demotivation can readily set in. However, surely the point here is that irrespective of the system, the Spirit motivates, and learning can happen even for the love of it. 
The student can then well go the "second mile", doing far more than the minimum that is the common habit of students. Actually the joy of learning can also follow, an emotional satisfaction closely related to that given by spiritual experience. Not surprisingly the third of the Galatian "fruits" then also follows in the peace experienced at examination time.

A further aspect of the work of the Spirit that is very relevant to the theological enterprise is that of guidance. Popular Christianity is very used to the idea of the leading of the Spirit; he is the one who relates the Christian to the mind of God (1 Cor 2:11). The other side of this is that there is a need to relate theology to the context. There is often a tendency to get distracted by interesting ideas and to drift off and investigate matters which are quite frankly no use at all, even if they may well be true. There is a well-known story that the academics in Constantinople were discussing the number of angels on a pinhead as the Moslems were succeeding in entering the city! One of the gratifying results of the Charismatic renewal is that it has spawned a great interest in the practical outworking of Christianity; "how to" books fill the bookshops. Even if the stress still tends to fall on personal experience and the ability to cope with the pressures of modern life, there is a growing concern with the problems of the world outside the church. The Spirit has bonded Christians to the rest of creation. It is notable that straight after his baptism and the descent of the Spirit upon the Messiah, Jesus' ministry was defined first by the temptations and then by the oft-quoted sermon in the synagogue at Nazareth (Lk 4:18f).

A final factor here by which spiritual growth has a decidedly beneficial impact on the academy is that the bonding of the Spirit operates also between the students. Far from opposing, and so often hindering, each other in academic competition, there can be mutual support. This can take several forms, from the sharing of the benefits of research, to discussion of teaching material. This should extend even to the care of library material in a way which does not deprive other students of limited resources. There should be no defacing, stealing, unnecessary retention or deliberate misplacing of material. Other academic vices, to say nothing of plagiarism or other forms of cheating, should be unthinkable. Of course if education is properly motivated, these should not become an issue.

However, the nature of the Person and work of the Spirit are such that there is a natural tendency to neglect, ignore and even exclude him. This may well mean that he is effectively marginalised from academic theology. Taylor (1971:5) bitingly asks how many projects have delayed waiting for the Spirit; we take him for granted. "Mr Pentecost", David du Plessis once said that "the Spirit is a gentleman" (Bennett \& Bennett 1974:99); his services are available, but he does not force himself onto us. It must be stressed here that the activities of the Spirit need to be specifically used, just as the charismata may well be present but dormant unless specifically practised. In any case, what is being enhanced by the action of the Spirit is within the capability of human reason in any case. Human nature then being what it is, there is an ongoing temptation to reject or ignore the help offered by the Spirit. It is always humbling to accept help!

It will also be the case that the academic enterprise is naturally easier and therefore more attractive than the direct experience of the Spirit. Perhaps a good analogy here is that it is easier and usually more pleasant to eat food that has been prepared by others than the basic ingredients; it is easier to talk and to learn about God than to experience him directly. Certainly this is more "comfortable", but this can easily neglect the work of the "Comforter" who can give a delight in the primary experience. 


\section{Empowerment}

The whole point of theological training is surely the production of effective Christian workers who are able to build up the church and minister to the community. It is a real tragedy when the complaint is made that the atmosphere of the academy is not helpful to spiritual development (Laurentin 1977:184). Part of this is the intellectual knowledge that is essential not only to be passed on to those ministered to, but the avoidance of mistakes that a knowledge of history and theology can alert one to. The ideal of a well educated clergy was one of the principles of the Reformation (Rooy 1988:65). At the same time responsible training must go beyond the theoretical foundation; as with any profession, academic knowledge must be complemented by practical skills.

But in the Christian ministry there is a further facet that is essential, and this also flows from the work of the Spirit as vinculum amoris, for the Spirit enables the bond between the minister and those ministered to. Without this link, the most thorough intellectual training and the most refined skills will be ineffective. As the ministry of the Christian worker is fundamentally spiritual, it demands the work of the Spirit. In preaching, liberty is given through the Spirit (Strauss 1954:85). As earlier noted, the words of the speaker require the breath of the Spirit. Perhaps the comment that the young preacher wrote in his notes, "argument here is weak, shout louder" is not so far out! The very real danger is that if the academy neglects the work of the Spirit in its activity of equipping prospective ministers, these will go into service ill-equipped, unaware of the most fundamental aspect of their empowerment, the help of the Spirit.

Again there is a danger of so stressing this Spiritual aspect that the other is lost. One of the features of the Charismatic renewal is what is termed "body ministry", the realisation that if God does indeed give specific charismata to the church as a whole. They are not so much given to individuals, but for the church (Hummel 1993:245). In this case these are all necessary for the church, and should be used (cf Hummel 1993:73). There is an effective repudiation of the traditional practice of the whole work of the church being concentrated in one of two individuals, the ordained clergy (Watson 1978:247f). Not only does such a practice infer that the Spirit has given unnecessary gifts to the rest of the church, but there is no New Testament justification for seeing all the charismata located in one person.

But again, the fact that the Spirit uses what is already present puts the responsibility on those who are "gifted" to acquire the intellectual and practical ability to use them effectively. Short courses, able to be attended by disciples without excessive disruption either of their lives as a whole, as three or more years of full-time study inevitably does, or of their role in the church and in society, could well be a means of responding to this understanding of the ministry.

There is no denial here that some people have a specific ministry which demands work fulltime. The church has a responsibility to recognise those that God has called, not of course just to go along with anybody who thinks they would like to minister! It is naturally the same principle that applies to the scripture, where the church does not give it its authority, but recognises it. And then of course the church accepts the duty of ministering to them; this specific form of bonding is also a work of the Spirit, and it is notable that unlike most "mainline" churches, the Charismatic churches do not struggle to motivate giving! What should then happen however is that the prime duty of the set-apart ministry is the equipping of the rest (Eph 4:18), so that they can effectively use their gifts. This must necessarily motivate a curriculum in the academy that facilitates such a role for those who will attend. 


\section{The 'Spirit' of the Academy}

In the past, the goal of training has been largely intellectual, especially when it was entrusted to the universities, and understandably so. But although this had definite advantages for the goals of the churches (Williams 1997), it often had the result that ministers were reduced to intellectuals, and Christianity to the assent to truth. Here the word "reduced" is exactly correct. What the Charismatic renewal has done is to restore the spiritual dimension. Faith has become not just a matter for the mind, but for the whole person, something seen in the physical activity in charismatic services. It has become something for the whole human person, and reflects a relationship to all the Persons of the Trinity.

It would seem logical for Christian training to reflect this wholism; how can this best be accomplished? The realisation that the goal of training is more than mental must necessarily modify what is done. But this in itself is not just intellectual, a matter for human activity and decision, but itself is an effect of the Spirit. What is then gratifying is that the goal of producing men and women who are spiritually as well as mentally empowered is not the result of just a change in human curriculum, but is itself empowered and enabled by that same Spirit.

Firstly, the Spirit, as holy, seeks to produce wholeness, so a goal of a holistic education would be consistent with his character. Secondly, as the vinculum amoris, he enables a fuller nexus of relationships, so with the whole Trinity, and with the church as a whole. And thirdly, the Holy Spirit acts primarily on the human spirit, relating it to that of God, producing motivation to live the life that God wants. An inadequate goal is a guarantee of ineffectiveness, but once the will or "spirit" is correct, the rest follows. Ethical choice and decisions are made in accordance with that, and as such are correct. The same is true of the human organisation that is called the academy. Once its aim or goal is correct, the details should follow.

But once again, the Spirit is a gentleman; he does not compel (Bennett \& Bennett 1974:70)! May his church become sensitive to his promptings, and become obedient. Effectiveness will follow.

\section{BIBLIOGRAPHY}

Bennett, D \& R 1974. The Holy Spirit and you: A study-guide to the Spirit-filled life. New ed. Eastbourne: Kingsway.

Boff, L 1988. Trinity and society. Maryknoll, New York: Orbis.

Bruner, FD 1970. A theology of the Holy Spirit: The Pentecostal experience and the New Testament witness. Grand Rapids: Eerdmans.

Dunn, JDG 1975. Jesus and the Spirit: A study of the religious and charismatic experience of Jesus and the first Christians as reflected in the New Testament. London: SCM.

Feilding, CR 1966. Education for ministry. Dayton, Ohio: American Association of Theological Schools.

Foakes Jackson, FJ 1914. The history of the Christian Church: From the earliest times to AD 461. $6^{\text {th }}$ ed. London: George Allen \& Unwin.

Gaffin, RB (jr.) 1996. A cessationist view. In Grudem (ed.) 1996, 25-64.

Grudem, W (ed.) 1996. Are miraculous gifts for today? Four views. Leicester: Inter-Varsity.

Hendry, GS 1965. The Holy Spirit in Christian Theology. rev ed. London: SCM. 
Hummel, CE 1993. Fire in the fireplace: Charismatic renewal in the nineties. Downers Grove, Ill; InterVarsity.

Laurentin, R 1977. Catholic Pentecostalism. London: Darton, Longman \& Todd.

Moule, CFD 1978. The Holy Spirit. London \& Oxford: Mowbrays.

Oss, DA 1996. A Pentecostal/Charismatic response to Robert L Saucy. In: Grudem (ed.) 1996, 164-71.

Packer, JI 1995. Keep in step with the Spirit. Leicester: Inter-Varsity.

Pinnock, CH 2001. Most moved mover: A theology of God's openness. Grand Rapids: Baker Academic.

Porter, SE 1995. Shaking the Biblical foundations? The Biblical basis for the Toronto Blessing, in Porter, SE \& Richter, PJ (eds.) The Toronto Blessing - or is it? London: Darton, Longman \& Todd.

Rahner, K 1970. The Trinity. London: Burns \& Oates.

Rooy, S 1988. Historical models of theological education, in Padilla, CR (ed.) New alternatives in theological education. Oxford: Regnum.

Rowdon, HH 1968. London Bible College: The first twenty-five years. Worthing, UK: Henry E Walter.

Strauss, L 1954. The third Person: Seven devotional studies on the Person and work of the Holy Spirit. New York: Loizeaux Brothers.

Swaggert, JC1980. Hyper-faith. A new gnosticism? Pretoria: Betel (distributors).

Von Rad, G 1968. The message of the prophets. London: SCM.

Watson, D 1978. I believe in the Church: With study guide. London: Hodder \& Stoughton.

Wheeler Robinson, H 1928. The Christian experience of the Holy Spirit. London: Nisbet.

Williams, DT 1997. University or Seminary? Reflections on the return of the Federal Theological Seminary to Fort Hare. In: Abrahams, SP, Punt, J \& Williams DT (eds.) Theology on the Tyume. Alice: Faculty of Theology, University of Fort Hare 1-13.

Williams, DT 2002. What is life? Koers 67(3) 271-82.

Williams, JR 1971. The era of the Spirit. Plainfield, NJ: Logos International. 